\title{
Ending the Code of Silence on Abductions of Aid Workers
}

\author{
Fabrice Weissman \\ Centre de Réflexion sur l'Action et les Savoirs humanitaires, Fondation MSF; fabrice.weissman@paris.msf.org \\ Translated by Nina Friedman
}

\begin{abstract}
This article discusses the policy of absolute secrecy on abductions adopted by aid organisations. It argues that the information blackout on past and current cases is to a large extent a function of the growing role of private security companies in the aid sector, which promote a 'pay, don't say' policy as a default option, whatever the situation. The article contends that secrecy is as much an impediment to resolving current cases as it is to preventing and managing future ones. It suggests abandoning the policy of strict confidentiality in all circumstances - a policy that is as dangerous as it is easy to apply - in favour of a more nuanced and challenging approach determining how much to publicise ongoing and past cases for each audience, always keeping in mind the interests of current and potential hostages.
\end{abstract}

Keywords: kidnapping, security, accountability, duty of care, reputational risk, ransom, negotiations

Every year, dozens of national and international aid workers are kidnapped. Like governments and companies, most humanitarian organisations handle these events with the utmost secrecy. While Médecins sans Frontières (MSF), for example, publicly confirmed the abduction and release of staff members kidnapped in Kenya in 2011 and Syria in $2014,{ }^{1}$ the organisation made no effort to mobilise public opinion as a way to gain their freedom. Nor did it provide any official details about the circumstances, detention conditions, kidnappers or their demands.

Refusing to answer journalists' questions about current or past abductions, humanitarian organisations also tend to keep information from their own staff. Unless they personally know the managers handling the kidnappings, aid workers must rely on their organisation's public version of the facts (i.e. 'No comment') and the more or less credible information that appears in the media, which may describe the horrendous conditions in which the hostages are being held and the payment of ransom to criminal and political networks (Callimachi, 2014a, 2014b; Kiser, 2013). In the end, vital information about the abductions remains the monopoly of the political and criminal networks carrying them out, the aid-organisation crisis units handling them, the private security firms advising them and the intelligence services observing them.

Keeping the public and aid workers in the dark, however, is not always justified. In many cases, secrecy is as much an impediment to resolving current cases as it is to preventing and managing future ones.

\section{Current Cases}

\section{The Need to Control Information}

It goes without saying that handling abductions requires a certain degree of discretion. It is especially important to avoid sharing information that could be used by fake intermediaries claiming to be in contact with the kidnappers and their captives. A minimum level of secrecy is also necessary to counteract efforts by governments opposed to any negotiations with organisations labelled as 'terrorist' groups. Moreover, local and international mobilisation and public advocacy campaigns do not necessarily have a positive impact on kidnapping resolution. Those publicising a hostage-taking are seeking to turn it into a political issue, which runs the risk of raising the stakes.

On the other hand, by endowing the hostages with greater commercial and political value, mobilisation campaigns may serve to protect their lives and pressure those with the power to facilitate their release. British journalists have noted that the lack of information and public advocacy on behalf of aid workers David Haines and Allan Henning, who were abducted in Syria by the Islamic State (IS) in 2014, did not prevent their 
execution. On the contrary, the silence of their organisation and the media may have bolstered the jihadist movement's claim that they were spies, while enabling the British government to maintain, unchallenged, its intransigent no-negotiations policy (Dettmer, 2014; Simon, 2014).

In other words, while controlling information shared internally and with the public is one of the key factors in managing kidnapping cases, it does not always follow that a complete media blackout is necessary.

\section{'Pay, Don't Say' Dogma}

Aid organisations' preference for quietly managing kidnapping cases is partly a function of private security companies' growing role in advising and, especially, training the organisations' managers on this issue (Neuman and Weissman, 2016). Former members of intelligence services or security forces turned security advisors spend countless hours training aid workers on 'how to manage kidnapping crises'.

The policy advocated almost routinely by these experts can be summed up as 'Pay, don't say'. In the eyes of private security firms, 'kidnapping can be reduced to a simple business negotiation ${ }^{2}$ that requires the strictest confidentiality. According to Alain Juillet, former intelligence director at the DGSE (the French externalintelligence agency) and senior advisor at Orrick Rambaut Martelet:

The Americans and British have learned that using private negotiators simplifies efforts by focusing on coming to an agreement about the ransom payment, which is generally paid by an insurance company. When the negotiator is the State, the hostage-takers know they can get much more than a simple ransom in exchange for releasing the hostage, such as supplies, the release of prisoners, and public statements. In addition, media coverage about a [government] effort shines an even greater light on the employees, who then become special targets.

(Défis, 2014) ${ }^{3}$

In fact, according to negotiators for RAID and GIGN (elite tactical units of the French police), '[Multinational] companies, which are overinsured, have become accustomed to paying ransom. It's a whole attitude and system. They don't make waves; they just pay' (Moisan, 2013).

Advised by the same private security companies, aid organisations seem to have adopted the same K\&R (kidnapping and ransom) policies practised by large companies. These policies are based on the following principles: use business transactions to resolve abductions, pay for ransoms with insurance policies, rely on experts (generally provided by the insurance company), practise strict confidentiality concerning the case's management and outcome and consistently deny any transaction in public. Designed for companies that wish to continue business as usual, this set of policies has become the default option for many humanitarian organisations regardless of the situation.

\section{'Making Waves'}

MSF has learned, however, that 'making waves' is sometimes the best way to secure the safe and sound release of our colleagues, often without making any material concessions. No overarching theory applies to every situation. For example, while publicly holding Russian and Dagestani deputies to account for the abduction of Swiss MSF head of mission Arjan Erkel in Dagestan in 2002 accelerated his release (McLean, 2016), the Congolese militias who are likely holding the four MSF staff members abducted in the DRC on 11 July 2013 seem to be completely indifferent to any type of concession or public pressure.

Furthermore, history shows that the mission of humanitarian organisations (particularly medical groups), the services they provide to wounded civilians and fighters and their access to the media and their audiences give them other means of pressure and negotiation than those available to companies. Out of fifteen long-term kidnappings handled by MSF since the 1990s, only a minority was resolved by a commercial transaction. From the Caucasus to Colombia, MSF has used political pressure to secure the release of some of its colleagues, ${ }^{4}$ while others have managed to escape. ${ }^{5}$

\section{Past cases}

\section{Omerta on Solved Cases}

Routinely keeping abductions secret once the hostages have been freed is just as debatable. According to most security experts, ${ }^{6}$ aid organisations will only encourage other kidnappers to go after them if they publicly announce staff abductions, particularly when the kidnapping is resolved by a commercial transaction. Unless they adopt a systematic and intransigent policy of not negotiating with kidnappers, ${ }^{7}$ humanitarian organisations will have to hide any transactions that led to the release of their colleagues.

This white lie is all the more necessary since aid organisations could face a public backlash and even state prosecution if they were to reveal transactions with criminal organisations and terrorists. Lastly, there is no benefit in making abductions an issue of public debate. Pirates and other criminal groups do not care about their image or public pressure, while jihadist groups like al-Qaida openly acknowledge relying on kidnappings for 
money. These are the reasons regularly brought up by humanitarian and security circles to justify keeping past cases secret.

They are not entirely without basis. It would clearly be inadvisable to consistently advertise the amount paid to secure the release of a hostage or reveal the role played by an intermediary who, for example, had decisive influence over the kidnappers. That being said, all a criminal network needs to know is that an organisation is wealthy and cares about the life of its employees for staff members to be considered potential targets. Further, governments show a certain degree of tolerance towards violations of their own laws that criminalise ransom payments. Following the uproar sparked by its intransigence over the abduction of journalist James Foley, who was executed by the IS in Syria on 18 August 2014, the US government revised its policy. It said families trying everything possible to save a loved one from a terrorist organisation like the IS would not be prosecuted (Dreazen and Jakes, 2015).

Therefore, while it is advisable to discuss previous cases with discretion, nothing justifies maintaining an information blackout, especially since secrecy hinders improvements to kidnapping prevention and risk management.

\section{Appeal for a Minimum Level of Transparency (Rather than Complete Transparency)}

Rachel Briggs, security researcher and Executive Director of Hostage US, a non-profit organisation that provides support to hostages and their families, believes that the fight against kidnapping networks must focus on three priorities: reducing opportunities for kidnapping, particularly by limiting the number of potential victims in high-risk areas; sharing information and expertise acquired by people and organisations that have dealt with the problem; and increasing the 'cost' of the social, political and criminal penalties incurred by kidnappers. ${ }^{8}$

In our opinion, these objectives are completely valid for aid organisations. All, however, require a minimum level of internal and public transparency concerning the abduction of humanitarian workers, which means breaking the code of silence about past cases.

It is impossible to increase the political costs of aidworker abductions without starting to publicly acknowledge their existence. In practice, secrecy helps shield local and international accountability, thus contributing to the continuation of a system that diverts aid resources to criminal organisations, their political sponsors and security and insurance companies. If there's one deterrent against potential kidnappers, as weak as it may be, it's publicising their crimes and their consequences.

Contrary to conventional wisdom, few political and military organisations - including jihadist movements, which claim to be champions of moral rectitude - openly acknowledge prospering from human trafficking and depriving a population of humanitarian aid for the sole purpose of selling a few aid workers on the hostage market. The IS's embarrassment about the abduction of MSF staff, as evidenced by its efforts to justify its actions to the local population and the fact that it did not dare include these kidnappings in its propaganda films, shows that aid workers do have some means of pressuring captors, including groups as radical and determined as the IS.

Similarly, there are no 'purely criminal' abductions, whose perpetrators are completely impervious to any social or political pressure. To act, criminal networks need support from citizens and authorities. ${ }^{9}$ Their actions may give rise to social and political backlash, increasing the costs of their crimes. According to sociologist Mark Turner, 'politics is potentially a part of any kidnapping, whatever the motivation of the kidnappers and even if they desire to keep politics out' (Turner, 1998: 145-60).

As a result, discussing abductions publicly does not automatically single out a humanitarian organisation as a special target but rather as a 'sensitive' one - not to mention that by breaking their code of silence, these organisations could better explain their operational decisions. In MSF's case, for example, discussing the circumstances surrounding its volunteers' kidnapping by the IS in 2014 would have enabled the organisation to explain why it refused to work in the areas under the group's control. Due to the lack of any explanation, this refusal was interpreted as evidence of MSF's political alignment with those fighting the IS.

Humanitarian organisations cannot hope to learn lessons from their experiences and counteract the influence of private security firms, if they continue to hide previous cases under a shroud of secrecy. Instead of importing the $\mathrm{K} \& \mathrm{R}$ policies of the major profit-driven companies, aid organisations must be able to review their experiences, discuss them and learn the necessary practical and political lessons. Such efforts are impossible without a minimum of internal and external transparency. As long as humanitarian organisations seek to erase any trace of kidnappings from public scrutiny, they will also be forced to do the same internally for fear of leaks.

Lastly, transparency is essential to inform volunteers about the dangers they face and limit their exposure in high-risk areas. While the code of silence is supposed to protect aid organisations from future kidnappers as well as legal and reputational risks, it may expose them to the latter. In other words, they may end up being condemned by the law and public opinion for not having adequately informed their staff about the dangers 
confronting them or doing everything possible to limit the risks, beginning with documenting and learning lessons from their experiences. By keeping silent about current or past cases, humanitarian organisations are also breaking their bond of trust with their volunteers and even, in MSF's case, violating their own charter, which states that volunteers are supposed 'to understand the risks and dangers of the missions they carry out'.

We are not suggesting replacing the code of complete silence with total transparency. Rather, we are recommending abandoning the policy of strict confidentiality in all circumstances - a policy that is as dangerous as it is easy to apply - in favour of a more nuanced approach considering each situation and audience, determining how much to publicise ongoing and past cases and always keeping in mind the interests of current and potential hostages.

\section{Notes}

1 Radio Télévision Belge Francophone (2014); Médecins sans frontières (2013).

2 In the words of Jeff Green, directeur of Griffin Underwriting, quoted by Dorothée Moisan (Moisan, 2013: 93).

3 And Dan Johnson, Manager of Special Projects - Security at Anadarko Petroleum, says: 'We believe that kidnap for ransom is entirely a financial negotiation and that we can bring about a resolution financially by coming to an agreed price with the kidnappers' (Leslie, 2011).

4 Abducted in Chechnya in January 2001 by a group of Islamist fighters, the Dutch section head of mission was released after 26 hours, and a letter of apology was published by his captors on the website kavkaz.org. Seeking support from the international community, the armed opposition took advantage of his release to announce its decision to 'ban all kidnappings of aid workers'. In Colombia, an MSF volunteer held for six months by the Guevarista Revolutionary Army guerrilla movement was unconditionally released on 30 January 2001 through the mediation of a third country involved in negotiations between armed Colombian groups and the government. MSF, which had confirmed the abduction of its employee in the media, played an active role encouraging the mediators to intervene and convincing the guerrillas and its allies of the benefit of an unconditional release.

5 For example, Christophe André, an administrator for MSF France, was abducted in Chechnya in July 1997 but escaped his captors on 20 October of the same year. Guy Delisle (2016) recounted the story of his captivity and escape in the form of a graphic novel called S'enfuir, récit d'un otage.

6 The experts to whom we are referring and whose arguments we are summarising are the security specialists we met during discussions within MSF about its kidnapping policy.

7 In reality, this policy is impractical and ineffective. Even governments that insist they 'never negotiate with terrorists', such as Russia, the United States and Israel, cannot consistently adhere to this policy due to the political costs involved (sacrificing hostages) and the low, long-term chances of success. For a bibliographic review and an analysis based on mathematical game-theory models to demonstrate that a no-negotiations policy has a poor chance of succeeding, see Bapat (2006: 213-29) and Lapan and Sandler (1988: 16-21).

8 'Rather than simply looking at the issue of ransoms, we should have a constructive debate around the key objectives: taking precautions to reduce the opportunity for kidnapping; ensuring that information and expertise about good practice is accumulated; and increasing the risks for kidnappers' (Briggs, 2001: 31). These recommendations are based on the conventional wisdom that policies seeking to fight kidnapping by banning ransom payments have all ended in failure. 'Experience elsewhere has shown that it is practically impossible to stop anyone paying a ransom, even where laws are introduced. ... Because money is fairly easy to transfer, even if one's assets are frozen, such laws are often almost impossible to police. Instead of stopping the payment of ransoms, they can deter people from reporting the crime, or change the way that the transaction is carried out' (ibid:: 23).

9 Based on examples from the United States in the 1930s, historian Kathleen J. Frydl argues that there is a close relationship between kidnapping practices and the structure of and challenges to state power: 'Kidnapping is an archetypal challenge to state authority: it is a crime against a person that, if unchecked, makes it clear that "people" (and not the state) rule. The ascent of the snatch racket marks a moment when opportunities for criminals outstripped both the capacity and perception of state power, and its diminution signals a significant reordering of that perspective and structure of state power' (2006: 18-44).

\section{Bibliography}

Bapat, N. A. (2006), 'State Bargaining with Transnational Terrorist Groups', International Studies Quarterly, 50:1, 213-29.

Briggs, R. (2001), The Kidnapping Business (London: The Foreign Policy Centre).

Callimachi, R. (2014a), 'The Horror before the Beheadings', New York Times, 25 October, http://goo.gl/EEQS7a (accessed 28 June 2019).

Callimachi, R. (2014b), 'Paying Ransoms, Europe Bankrolls Qaeda Terror', New York Times, 29 July, http://goo.gl/safB5A (accessed 28 June 2019).

Défis (2014), Business en milieu hostile. La protection des entreprises à linternational (Paris: Ministère de l'intérieur).

Delisle, G. (2016), S'enfuir. Récit d'un otage (Paris: Dargaud).

Dettmer, J. (2014), 'The Media Blackout on Hostages Helps ISIS', Daily Beast, 2 September, http://goo.gl/OaBvmr (accessed 28 June 2019). 
Dreazen, Y. and Jakes, L. (2015), 'Hostage Review Will Make It Easier for Families to Pay Ransoms', Foreign Policy, 22 June, https:// foreignpolicy.com/2015/06/22/hostage-review-will-make-it-easierfor-families-to-pay-ransoms/ (accessed 28 June 2019).

Frydl, K. J. (2006), 'Kidnapping and State Development in the United States', Studies in American Political Development, 20, 18-44.

Kiser, M. (2013), 'How Somali Pirates and Terrorists Made Bank off Two Western Hostages', Vocativ, 10:24 ED, http://goo.gl/n7q5CE (accessed 28 June 2019).

Lapan, H. E. and Sandler, T. (1988), 'To Bargain or Not to Bargain: That Is the Question', American Economic Review, 78: 2, 16-21.

Leslie, B. (2011), 'In Harm's Way', Canadian Insurance Risk Manager, available at www.citopbroker.com/your-business/in-harms-way-2958 (accessed 28 June 2019).

McLean, D. (2016), 'The Shadowy Theatre of Kidnappings. An Account of Arjan Erkel's Rescue', in Neuman, M. and Weissman, F. (eds), Saving Lives and Staying Alive: Humanitarian Security in the Age of Risk Management (London: Hurst and Co, pp. 127-43).
Moisan, D. (2013), Rançons. Enquête sur le business des otages (Paris: Fayard). Médecins sans frontières (2013), 'Somalia: Kidnapped MSF staff released after 644 days', 18 July, www.msf.ie/article/somaliakidnapped-msf-staff-released-after-644-days (accessed 28 June 2019).

Neuman, M. and Weissman, F. (2016), 'Humanitarian Security in the Age of Risk Management', in Neuman, M. and Weissman F. (eds), Saving Lives and Staying Alive: Humanitarian Security in the Age of Risk Management (London: Hurst and Co, pp. 1-17).

Radio Télévision Belge Francophone (2014), 'Les employés de MSF enlevés en Syrie, dont un Belge, ont été libérés', 15 May, www. rtbf.be/info/belgique/detail_les-employes-de-msf-enleves-en-syriedont-un-belge-ont-ete-liberes?id=8269986 (accessed 28 June 2019).

Simon, J. (2014), 'Is It Time to End Media Blackouts?', Columbia Journalism Review, 3 September, http://m.cjr.org/164394/show/ 09239ac3b655cee6f021e5def773aad4/ (accessed 28 June 2019).

Turner, M. (1998), 'Kidnapping and Politics', International Journal of the Sociology of Law, 26, 145-60. 